\title{
Hodnocení stavu útvarů povrchových vod v České republice pro 3. plánovací období plánů povodí
}

\section{TOMÁŠ MIČANÍK, PETR VYSKOČ, HANA PRCHALOVÁ, MAREK POLÁŠEK, DENISA NĚMEJCOVÁ, MARTIN DURČÁK, PAVEL RICHTER}

Klíčová slova: hodnocení stavu povrchových vod útvar povrchových vod - chemický stav - ekologický stav/potenciál

\section{Surface Water Status} Assessment for the Third Cycle River Basin Management Plan of the Czech Republic

\author{
TOMÁŠ MIČANÍK, PETR VYSKOČ, HANA PRCHALOVÁ, \\ MAREK POLÁŠEK, DENISA NĚMEJCOVÁ, \\ MARTIN DURČÁK, PAVEL RICHTER
}

Keywords: assessment of surface water status -

surface water body - chemical status - ecological status/potential

\section{SOUHRN}

Článek seznamuje se souhrnnými výsledky hodnocení chemického stavu a ekologického stavu/potenciálu útvarů povrchových vod kategorie "řeka" a kategorie "jezero" za období 2016-2018, které slouží jako podklad pro zpracování plánů povodí 3. plánovacího období (2021-2027) na všech jeho úrovních: plánů dílčích povodí, národních plánů a plánů mezinárodních povodí Labe, Dunaje a Odry. Hodnocení stavu bylo realizováno Výzkumným ústavem vodohospodářským, T. G. Masaryka, v. v. i., a Biologickým centrem Akademie věd ČR ve spolupráci s Hydrosoftem Veleslavín, s. r. o., Českým hydrometeorologickým ústavem a Povodím VItavy, s. p. Pro hodnocení byly využity výsledky monitorovacích programů státních podniků Povodí Labe, Vltavy, Ohře, Moravy a Odry a Českého hydrometeorologického ústavu (ČHMú).

$\checkmark$ nevyhovujícím chemickém stavu je vzhledem k použití principu „one out all out“ 51,1 \% útvarů povrchových vod kategorie „řeka“ (z celkem 1045 útvarů) a 20,5 \% útvarů kategorie "jezero" (ze 73 útvarů), přičemž u 16,7 \% útvarů povrchových vod kategorie "řeka" a u 43,8 \% útvarů kategorie "jezero" byl jejich chemický stav označen jako "neznámý“. V nevyhovujícím ekologickém stavu/potenciálu je 94,6 \% útvarů povrchových vod kategorie „řeka” (z 1045 útvarů) a 86,3 \% útvarů kategorie "jezero" (ze 73 útvarů).

Pro hodnocení byly z větší části využity aktualizované a v některých prípadech zcela nové metodické postupy. Zároveň se změnily monitorovací programy - pro 3. období plánů se obecně monitorovalo více ukazatelů a složek. Kvůli tomu nelze jednoduše porovnávat výsledky ekologického stavu a potenciálu a chemického stavu mezi 2. a 3. plánovacím obdobím. Vzhledem k rozsahu a povaze problematiky není cílem tohoto článku podrobnější analýza souvislostí, príčin a faktorů ovlivňující výsledky předkládaného hodnocení stavu útvarů povrchových vod jako rovněž podrobnější srovnání s výsledky hodnocení stavu útvarů povrchových vod ve 2. plánovacím období.

\section{SUMMARY}

The aim of this article is to acquaint the professional public with the summary results of the assessment of chemical status and ecological status/potential of surface water bodies "river" and "lake" categories in the Czech Republic for 2016-2018. This assessment is one from the basis for preparation of the Third River Basin Management Plan (2021-2027) at all its levels: sub-basin plans, national plans, and international plans of the Elbe, Danube, and Oder river basin districts. The status assessment was carried out by T. G. Masaryk Water Research Institute p.r.i., and by Biology Centre CAS in cooperation with Hydrosoft Veleslavín and the Czech Hydrometeorological Institute. The results of the surface water monitoring programmes were used for status assessment.

Due to the "one out - all out" principle, $51.1 \%$ of surface water bodies in the "river" category (out of a total 1,045 river bodies) and 20.5\% of surface water bodies in the "lake" category (out of 73 lakes) failed to achieve good chemical status. $94.6 \%$ of surface water bodies in the "river" category and $86.3 \%$ of surface water bodies in the "lake" category failed to achieve good ecological status. $16.7 \%$ of surface water bodies in the "river" category and $43.8 \%$ in the "lake" category were not classified due to missing monitoring data.

The failure to achieve good chemical status was mainly influenced by the occurrence of polycyclic aromatic hydrocarbons, namely fluoranthene and benzo(a)pyrene. Some new priority substances, such as cypermethrin, dichlorvos, and PFOS did not achieve good chemical status in all of the monitored profiles; nevertheless, the scope of their monitoring is still very low (4\% of profiles). A similar situation was found in the case of mercury and polybrominated diphenyl ethers in biota monitoring. The limiting parameter for achieving good ecological status/potential is still the total phosphorus and dissolved oxygen for the "river" category and the total phosphorus and transparency for the "lake" category. From the evaluated biological quality elements, phytobenthos and benthic macroinvertebrates for the category "river" and phytoplankton for the category "lake" most often contributed to failure in good ecological status/potential. 
ÚVOD

V rámci prípravy již 3. plánů povodí na období 2021-2027 bylo potřeba provést hodnocení stavu $v$ útvarech povrchových vod $z$ dat monitoringu vod realizovaných jednotlivými správci povodí a ČHMÚ. Toto hodnocení je významným podkladem pro zpracování všech úrovní plánů povodí a jednotlivým správcům povodí slouží jak k formulování opatření k dosažení dobrého stavu vod, tak jako podklad i v dalších oblastech výkonu vodohospodářských činností. Hodnocení se provádí pro každý vodní útvar kategorie "řeka" a kategorie "jezero“. Rozhodným obdobím pro zpracování hodnocení stavu bylo obdobi 2016-2018, v některých prípadech předchozí hodnocené období 2013-2015 [1]. Hodnocení bylo provedeno v souladu s požadavky evropské [2] i národní legislativy [3-4] podle aktualizovaných metodických postupů hodnocení, které jsou shrnuty v následující kapitole.

\section{POUŽITÉ METODICKÉ POSTUPY}

Hodnocení stavu útvaru povrchových vod se dělí na hodnocení chemického stavu a hodnocení ekologického stavu $\vee$ prrirozených útvarech povrchových vod a ekologického potenciálu v silně ovlivněných a umělých útvarech povrchových vod. Počet těchto útvarů za celou ČR je uveden v tabulce 1 .

Tabulka 1. Kategorie útvarů povrchových vod pro 3. plánovací období

\begin{tabular}{lll}
$\begin{array}{l}\text { Kategorie útvarů } \\
\text { povrchových vod }\end{array}$ & $\begin{array}{l}\text { Počet útvarů } \\
\text { povrchových vod }\end{array}$ & $\begin{array}{l}\text { Procento útvarů } \\
\text { povrchových } \\
\text { vod (\%) }\end{array}$ \\
\hline „,řka“ & $\mathbf{1 0 4 5}$ & $\mathbf{9 3 , 5}$ \\
\hline řeka - přirozený & 942 & 84,3 \\
\hline řeka - silně ovlivněný & 98 & 8,8 \\
\hline řeka - umělý & 5 & 0,4 \\
\hline "jezero“ & $\mathbf{7 3}$ & $\mathbf{6 , 5}$ \\
\hline jezero - silně ovlivněný & 69 & $\mathbf{6 , 2}$ \\
\hline jezero - umělý & 4 & 0,3 \\
\hline Celkem & $\mathbf{1 1 1 8}$ & $\mathbf{1 0 0}$
\end{tabular}

Proti 2. plánovacímu období (z hodnocení období 2010-2012) se sice počet útvarů povrchových vod změnil jen nevýrazně, podstatná změna ale nastala v převymezení silně ovlivněných útvarů kategorie „řeka“ v roce 2019. Důvodem byla úprava metodiky identifikace silně ovlivněných vodních útvarů, aby navazovala na vyhodnocení významnosti hydromorfologických vlivů. Celkem 49 vodních útvarů dríve určených jako „přirozený” bylo nyní vymezeno jako „silně ovlivněný"; naopak dríve 40 silně ovlivněných vodních útvarů bylo nyní vymezeno jako "přirozený".

Vyhodnocení bylo realizováno na základě reálně naměřených dat situačního a provozního monitoringu povrchových vod v tzv. reprezentativních profilech útvarů povrchových vod ( $v$ několika př́padech jeden reprezentativní profil sloužil pro vyhodnocení dvou nebo více útvarů kategorie „řeka"). Hodnocení je pak vztaženo na celý vodní útvar. Hodnoceno je období 2016-2018, poprípadě období 2013-2015 u biologických složek nebo ukazatelů chemického stavu, pokud v príslušných dílčích povodích nebyla novější data k dispozici. Při hodnocení bioty byla vzhledem k rotaci profilů po třech letech použita data z obou období v plném rozsahu.
It is difficult to compare the results of the assessment of chemical status and ecological status/potential between the Second and Third River Basin Management Plans due to adjustments and changes in the methodological procedures.

\section{INTRODUCTION}

As part of the preparation of the Third River Basin Management Plan for the period 2021-2027, it was necessary to carry out an assessment of the status of surface water bodies from water monitoring data carried out by individual river basin managers and the Czech Hydrometeorological Institute (CHMI). This assessment is an important basis for the elaboration of all levels of river basin plans and serves individual river basin managers both to formulate measures to achieve good water status, as well as a basis in other areas of water management activities. The assessment is performed for each water body of the "river" and "lake" categories. The decisive period for the preparation of the assessment of the situation was 2016-2018; in some cases it was the previous evaluated period, 2013-2015 [1]. The evaluation was carried out in accordance with the requirements of European [2] and national legislation [3-4] according to the updated methodological procedures of evaluation, which are summarized in the following section.

\section{METHODOLOGICAL PROCEDURES USED}

The assessment of surface water body status is divided into the assessment of chemical status and the assessment of ecological status in natural surface water bodies, and the ecological potential in heavily modified and artificial surface water bodies. The number of these bodies for the whole of the Czech Republic is shown in Table 1 .

Table 1. Surface water bodies - categories valid for the third planning cycle

\begin{tabular}{lll}
$\begin{array}{l}\text { Category of } \\
\text { surface water } \\
\text { bodies }\end{array}$ & $\begin{array}{l}\text { Number of } \\
\text { surface water } \\
\text { bodies }\end{array}$ & $\begin{array}{l}\text { Percentage of } \\
\text { surface water } \\
\text { bodies (\%) }\end{array}$ \\
\hline "river" & $\mathbf{1 , 0 4 5}$ & $\mathbf{9 3 . 5}$ \\
\hline river - natural & 942 & 84.3 \\
\hline river - heavily modified & 98 & 8.8 \\
\hline river - artificial & 5 & 0.4 \\
\hline “lake" & $\mathbf{7 3}$ & $\mathbf{6 . 5}$ \\
\hline lake - heavily modified & 69 & 6.2 \\
\hline lake - artificial & 4 & 0.3 \\
\hline Total & $\mathbf{1 , 1 1 8}$ & $\mathbf{1 0 0}$
\end{tabular}

Compared to the second planning cycle (from the evaluation in 2010-2012), the number of surface water bodies changed only slightly; however, a significant change occurred in the re-definition of heavily modified bodies of the "river" category in 2019. The reason was adjustment of the methodology for identifying heavily modified water bodies so that it follows up on the evaluation of the significance of hydromorphological effects. A total of 49 water bodies previously designated as "natural" have now been defined as "heavily modified"; in contrast, 40 previously "heavily modified" water bodies have now been defined as "natural". 
Přehled metodik použitých pro hodnocení stavu je uveden $v$ literatuře k tomuto článku [5-18]. V následujícím textu jsou zmíněny významné odlišnosti oproti predchozímu realizovanému hodnocení.

\section{Chemický stav}

Vưbec poprvé byla ve shodě se směrnicí 2013/39/EU a nařízením vlády č. 401/2015 Sb. hodnocena biologicky dostupná forma rozpuštěných kovů niklu a olova podle metodiky [17]. Ta závisí na koncentraci př́slušného rozpuštěného kovu, koncentraci rozpuštěného organického uhlíku (DOC), reakci vody $(\mathrm{pH})$ a vápníku (Ca). Biologicky dostupná koncentrace kovů vypočtená pomocí vhodných softwarových nástrojů $[19,20]$ je vždy nižší než koncentrace rozpuštěné formy kovu. Tím vyšlo hodnocení niklu a olova príznivěji než v hodnocení pro 2. plánovací období.

Zásadní změnou oproti předchozímu způsobu hodnocení byl př́stup k situacím, kdy v daném reprezentativním profilu nebyl monitorován žádný z ukazatelů chemického stavu. Stav takového útvaru byl z důvodu předběžné opatrnosti označen jako "neznámý" (dřive "dobrý"). Na základě expertního posouzení pak příslušný správce povodí mohl jeho stav označit jako „dobrý“ v prípadě, že $\checkmark$ hodnoceném útvaru povrchových vod neexistuje významný antropogenní vliv (bodového, difúzního nebo plošného charakteru znečištění).

\section{Ekologický stav/potenciál}

\section{ÚTVARY KATEGORIE ŘEKA}

\section{Všeobecné fyzikálně-chemické složky}

Pro hodnocení všeobecných fyzikálně-chemických ukazatelů útvarů povrchových vod kategorie „řeka“ za období 2016-2018 byla použita Metodika hodnocení všeobecných fyzikálně-chemických složek ekologického stavu útvarů povrchových vod tekoucích [11] a Metodika hodnocení všeobecných fyzikálně-chemických složek ekologického potenciálu útvarů povrchových vod tekoucích [15]. Naproti tomu pro 2. plánovací období byly pro hodnocení útvarů kategorie řeka použity "relaxované“ limity ukazatelů, a to stejné pro ekologický stav i potenciál (limitní hodnoty mezi dobrým a středním stavem/potenciálem v metodice [11] jsou nyní prísnější, než „relaxované" limity použité v hodnocení předchozích období). Kromě změny charakteristických hodnot je změna i v prípadě některých ukazatelů. Tím mohla být pro hodnocení ekologického potenciálu silně ovlivněných a umělých vodních útvarů pro kategorii řeka použita původní metodika [13] (v předchozím období plánů nemohla být použita, nebot limity pro ekologický potenciál byly v některých případech přísnější než limity pro stav). Proto nelze porovnávat výsledky hodnocení mezi druhým a třetím obdobím.

\section{Biologické složky}

Hodnocení biologických složek s výjimkou ryb bylo v rámci 3. plánovacího období provedeno podle dřivějších metodických postupů pro 2. plánovací období, do kterých byly zapracovány výsledky interkalibračního porovnání [21]. Zprísnění pưvodně nastavených hranic tříd, které byly použity pro 2. plánovací období, se dotklo biologické složky fytobentos a makrofyta. Změny v zatřídění výsledných hodnot EQR indexů jsou uvedeny v aktualizovaných metodikách [6, 7]. Metodika pro hodnocení biologické složky ryby byla přepracována [5]. Vychází sice z výpočetních postupů původní metodiky [22], ale byl revidován seznam taxonů včetně vlastností organismů (traits), doplněny nové vlastnosti (nepůvodnost taxonu) a byly upraveny parametry spolehlivosti hodnocení, které také ovlivnily, jaké kategorie vodních útvarů se mohou hodnotit, tj. hodnotí stav vodních útvarů pro kategorie 4.-9. řádu podle Strahlera. Nižši rády
The evaluation was carried out on the basis of the actual measured data of surveillance and operational surface water monitoring in the representative profiles of surface water bodies (in several cases, one representative profile was used to evaluate two or more bodies in the "river" category). The assessment is then applied to the whole water body. If no data were available in the period 2016-2018, the period 2013-2015 is assessed for Biological quality elements or chemical status parameters. Due to the rotation of the profiles after three years, data from both periods were used in full when evaluating biota.

An overview of the methodologies used to assess the status is given in the literature for this article [5-18]. The following text mentions significant differences from the previous evaluation.

\section{Chemical status}

For the first time, in compliance with Directive 2013/39/EU and Government Regulation No. 401/2015 Coll., the bioavailable form of dissolved metals of nickel and lead was evaluated according to the methodology [17]. It depends on the concentration of the respective dissolved metal, the concentration of dissolved organic carbon (DOC), and the reaction of water $(\mathrm{pH})$ and calcium $(\mathrm{Ca})$. The bioavailable concentration of metals calculated using appropriate software tools [19-20] is always lower than the concentration of the dissolved form of the metal. This resulted in a more favourable evaluation of nickel and lead than in the evaluation for the second planning cycle.

A fundamental change compared to the previous method of evaluation was the approach to situations where none of the chemical status indicators was monitored in the given representative profile. Due to precaution, the condition of such a body was designated as "unknown" (formerly "good"). Based on the expert assessment, the relevant river basin manager could designate its status as "good" if there was no significant anthropogenic pressure (point, diffusion, or surface nature of pollution) in the assessed surface water body.

\section{Ecological status/potential}

\section{BODIES IN THE "RIVER" CATEGORY}

\section{General physico-chemical quality elements}

The Methodology for the assessment of General physico-chemical quality elements of the ecological status of flowing surface water bodies [11] and the Methodology for the assessment of General physico-chemical quality elements of the ecological potential of surface water bodies [15] were used to evaluate general physico-chemical parameters of surface water bodies of the "river" category for 2016-2018. In contrast, for the second planning cycle, different limits were used for the evaluation of the "river" category bodies, both the same for ecological status and potential (limit values between good and moderate status/potential in the methodology [11] are now stricter than limits used in the evaluation of previous periods). In addition to the change in characteristic values, there is also a change in some parameters. Thus, the original methodology could be used to assess the ecological potential of heavily modified and artificial water bodies for the "river" category [13] (in the previous planning cycle it could not be used as ecological potential limits were in some cases stricter than status limits). Therefore, it is not possible to compare the evaluation results between the second and third cycle.

\section{Biological quality elements}

Evaluation of Biological quality elements (with the exception of fish) was carried out in the third planning cycle according to the previous methodological procedures for the second planning cycle, in which the results of the 
toků na rozdíl od předchozí metodiky nehodnotí, hodnocení by bylo nespolehlivé. Takže zatímco postupy a výsledky hodnocení ostatních biologických složek jsou z větší části porovnatelné s minulým obdobím, postupy hodnocení ryb srovnávat nelze, výsledky hodnocení lze porovnat jen obtižně.

Hodnocení biologických složek fytobentos a makrofyta v silně ovlivněných vodních útvarech je stejně jako $v 2$ 2. plánovacím období shodné s postupem hodnocení pro přirozené vodní útvary $[6,7]$. Hodnocení ekologického potenciálu makrozoobentosu a fytoplanktonu $v$ silně ovlivněných vodních útvarů bylo provedeno podle původních metodik $[9,10]$ a použitý postup je shodný pro 2. i 3. plánovací období. Změny v hodnocení biologických složek pro vodní útvary kategorie „řeka" shrnuje tabulka 2. intercalibration comparison were incorporated [21]. The tightening of the originally set class boundaries (used for the second planning cycle) affected the phytobenthos and macrophytes Biological quality elements. Changes in the classification of the resulting values of Environmental Quality Ratio (EQR) indexes are shown in the updated methodologies [6-7]. The methodology for the assessment of the biological quality element of fish has been revised [5]. Although it is based on computational procedures of the original methodology [22], the list of taxa (including traits) was revised, new traits were added (non-origin of the taxon), and assessment reliability parameters were modified; this also affected which water body categories can be assessed (i.e., it evaluates the condition of water bodies for categories of the $4^{\text {th }} 9^{\text {th }}$ Strahler stream order. Unlike the previous methodology, it does not evaluate lower stream orders: the evaluation would be unreliable. So, while the procedures and results of the evaluation of other Biological quality elements are for the most part comparable to the previous period, the procedures for the evaluation of fish cannot be compared: the evaluation results are difficult to compare.

As in the second planning cycle, the assessment of the phytobenthos and macrophyte Biological quality elements in heavily modified water bodies

Tabulka 2. Změny v hodnocení a výsledcich biologických složek kategorie „řeka“ mezi 2. a 3. plánovacím obdobím

\section{Změny} v hodnocení

FP

FB

MF

MZB

aktualizace hranic tříd

aktualizace hranic tříd v podtypu A úmoří

přirozené vodní útvary

shodné postupy, porovnatelné výsledky hodnocení
Severního moře na

základě interkalibrač-

ního cvičení, porov-

natelné výsledky

hodnocení $\checkmark$ typu Skupina 2 a typu

Skupina 4 na základě

interkalibračního cvi-

čení, porovnatelné

výsledky hodnocení shodné postupy, změna postupu porovnatelné výsledky hodnocení, těžko hodnocení

porovnatelné

výsledky hodnocení

\section{silně ovlivněné vodní útvary} shodné postupy, porovnatelné výsledky viz pririrozené útvary hodnocení

umělé vodní
útvary

nehodnotí se

viz přirozené útvary

\section{shodné postupy,}

porovnatelné výsledky viz přirozené útvary hodnocení

\section{Ryby}

$F P=$ fytoplankton; $F B=$ fytobentos $; M F=$ makrofyta; $M Z B=$ makrozoobentos

nehodnotíse nehodnotí se

viz prirozené útvary

nehodnotíse nehodnotí se

nehodnotí se

Table 2. Changes in biological element assessment and results of category "river" between second and third planning cycle

\section{Changes in} assessment

PP

identical procedures, comparable evaluation results

\section{Natural water bodies}

Heavily affected
water bodies

identical procedures, comparable evaluation results
PB

updating of class boundaries in subtype $A$ of the North Sea basin on the basis of intercalibration exercise, comparable evaluation results
MP

updating of class boundaries in type Group 2 and type Group 4 on the basis of intercalibration exercise, comparable evaluation results

\section{MZB}

identical procedures, comparable evaluation results
Fish

change in assessment procedure, difficult to compare evaluation results

\section{Artificial water} bodies not evaluated not evaluated not evaluated identical procedures, comparable evaluation see natural bodies results 


\section{Specifické znečišt'ující látky}

Hodnocení specifických znečištujících látek je stejné pro ekologický stav i potenciál. Pro hodnocení byla použita metodika z 2. období plánů a jediný rozdíl je $v$ tom, že pokud $v$ útvaru nebyl $v$ hodnoceném období sledován a/nebo klasifikován žádný ukazatel, byl ekologický stav/potenciál vodního útvaru označen jako „neznámý”.

\section{Hydromorfologie}

V 2. období plánů nebyly hydromorfologické složky hodnoceny a ani neproběhlo hodnocení významnosti hydromorfologických vlivů na úrovni celé ČR. Pro 3. období tedy vznikla metodika hodnocení významnosti hydrologických a morfologických vlivů [23] a podle ní byly v plánech identifikovány významné vlivy z hlediska hydrologického režimu, kontinuity a morfologických podmínek. Významné morfologické vlivy byly pak začleněny do výsledků ekologického stavu a potenciálu, ale jako podpưrná složka hodnocení biologických složek, takže nevstupovaly do principu „one-out - all-out“.

\section{ÚTVARY KATEGORIE JEZERO}

Hodnocení ekologického potenciálu jezer proběhlo shodnými metodickými postupy jako pro 2. plánovací období [12, 14], vzhledem k nedostatku dat však byla z biologických složek hodnocena pouze složka fytoplankton.

Stále obecně platí, že výsledný stav je dán nejhorším výsledkem hodnocení jednotlivých ukazatelů všech složek chemického stavu a ekologického stavu/potenciálu (s výjimkou hydromorfologie).

Postup spolehlivosti hodnocení ekologického stavu/potenciálu a chemického stavu byl upraven podle požadavků na reporting [24] a je definován v metodice [23]. Nově se spolehlivost určuje ve třech kategoriích (vysoká, strední a nízká).

\section{VÝSLEDKY}

Stav útvarů povrchových vod je dán chemickým stavem a ekologickým stavem, resp. ekologickým potenciálem v prípadě silně ovlivněných a umělých vodních útvarů. Výsledky hodnocení stavu agregované pro celou Českou republiku, ve vybraných prípadech i po jednotlivých ukazatelích, jsou stručně zpracovány formou tabulek, map a grafů v následujícím textu.

\section{Chemický stav}

Chemický stav je podle Rámcové směrnice pro vodní politiku 2000/60/ES [2] klasifikován jako "dobrý" nebo "nedosažení dobrého stavu“. Přitom stačí, aby byla překročena jakákoliv norma environmentální kvality z hodnocených prioritních látek, aby dobrý stav nebyl dosažen.

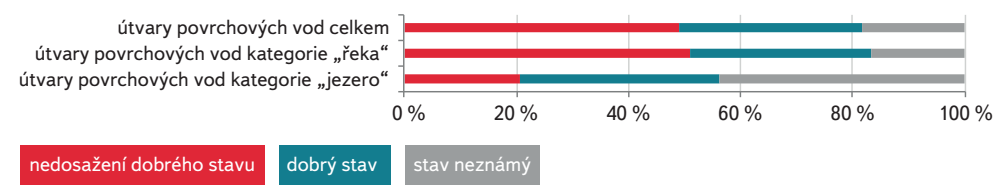

Obr. 1. Chemický stav útvarů povrchových vod kategorie "řeka" a "jezero" Fig. 1. Chemical status of surface water bodies in categories "river" and "lake"

Dobrý chemický stav byl dosažen ve 32,2 \% útvarů povrchových vod kategorie "řeka" a 36 \% útvarů kategorie "jezero" (obr. 1 a 2, tabulka 3). Dobrým chemickým stavem bylo pro všech 1118 útvarů povrchových vod klasifikováno 32,5 \% z nich, přičemž 18,4 \% útvarů nebylo klasifikováno, většinou z důvodu is identical to the assessment procedure for natural water bodies [6-7]. The assessment of the ecological potential of macrozoobenthos and phytoplankton in heavily modified water bodies was performed according to the original methodologies [9-10] and the procedure used is identical for the second and third planning cycles. Changes in the assessment of Biological quality elements for water bodies of the "river" category are summarized in Table 2.

\section{Specific pollutants}

The assessment of River Basin-Specific Pollutants (RBSP) is identical for ecological status and potential. The methodology from the second planning cycle was used for the evaluation. The only difference is that if no parameter was monitored and/or classified in the body during the evaluated period; the ecological status/potential of the water body was marked as "unknown".

\section{Hydromorphology}

In the second planning cycle, hydromorphological quality elements were not evaluated, nor was the evaluation of the significance of hydromorphological effects at the level of the entire Czech Republic. Thus, a methodology for assessing the significance of hydrological and morphological impacts [23] was created for the third cycle and, based on it, significant impacts were identified in the plans in terms of hydrological regime, continuity, and morphological conditions. Significant morphological impacts were then included in the results of ecological status and potential, but as a supporting quality element of the evaluation of Biological quality elements, so they did not enter the principle of "one-out - all-out".

\section{BODIES IN THE "LAKE" CATEGORY}

The evaluation of the ecological potential of lakes was carried out using the same methodological procedures as for the second planning cycle [12, 14]; however, due to the lack of data, only phytoplankton was evaluated from the Biological quality elements.

It is still generally true that the final status is given by the worst result of the evaluation of individual parameters of all quality elements of the chemical status and ecological status/potential (with the exception of hydromorphology).

The reliability procedure for the assessment of ecological status/potential and chemical status has been adjusted according to the reporting requirements [24] and is defined in the methodology [23]. Reliability is now determined in three categories (high, moderate, and low).

\section{RESULTS}

The status of surface water bodies is determined by the chemical status and ecological status, or ecological potential in the case of heavily modified and artificial water bodies. The results of the status assessment aggregated for the whole of the Czech Republic (in selected cases also by individual indicators) are briefly processed in the form of tables, maps, and graphs in the following text.

\section{Chemical status}

The chemical status is classified as "good" or "failing to achieve good status" according to the Water Framework Directive 2000/60/EC [2]. If any Environmental Quality Standard (EQS) of the evaluated priority substances is exceeded then good status is failing to achieve good status. 
chybějících dat z monitoringu a v některých případech kvưli nedostatečnému počtu měření za rok, a jejich chemický stav byl označen jako "neznámý”. Oproti výsledkům hodnocení chemického stavu povrchových vod pro 2. plánovací období (2010-2012) je nyní dobrým stavem hodnocen menší počet vodních útvarů (dř́ve 60,9\%). To je dáno několika faktory:

A. Pokud v daném reprezentativním profilu nebyl monitorován žádný z ukazatelů chemického stavu, jeho stav nebyl v aktuálním hodnocení pro 3. plánovací období označen jako "dobrý", ale z důvodu předběžné opatrnosti jako „neznámý”. Jen menší počet vodních útvarů byl následně správci povodí na základě expertního posouzení označen jako "dobrý“ (v případě, že v hodnoceném útvaru povrchových vod neexistuje významný antropogenní vliv). V hodnocení pro 2. plánovací období nebyl chemický stav klasifikován pouze ve čtyřech vodních útvarech (z 1121$)$.

B. Ve 3. plánovacím období se významně zvýšilo monitorování prioritních látek, což vedlo ke zvýšenému počtu nevyhovujících útvarů, které byly předtím označeny jako v dobrém stavu.
Good chemical status was achieved in $32.2 \%$ of surface water bodies in the "river" category and 36\% of bodies in the "lake" category (Figures 1 and 2, Table 3). Out of the entire 1,118 surface water bodies, 32.5\% of them were classified as having good chemical status; $18.4 \%$ were not classified, mostly due to missing monitoring data and, in some cases, due to insufficient number of measurements per year, and their chemical status was marked as "unknown". Compared to the results of the surface water chemical status assessment for the second planning cycle (2010-2012), a smaller number of water bodies (previously 60.9\%) is now assessed as having good status. This is due to several factors:

A. If none of the chemical status parameter was monitored in the given representative profile, its status was not marked as "good" in the current evaluation for the third planning cycle, but as "unknown" due to precaution. Only a small number of water bodies were subsequently marked as "good" by the river basin managers on the basis of an expert assessment (in the event that there is no significant anthropogenic pressure in the assessed surface water body). In the evaluation for the second planning cycle, the chemical status was not classified in only four water bodies (out of 1,121).

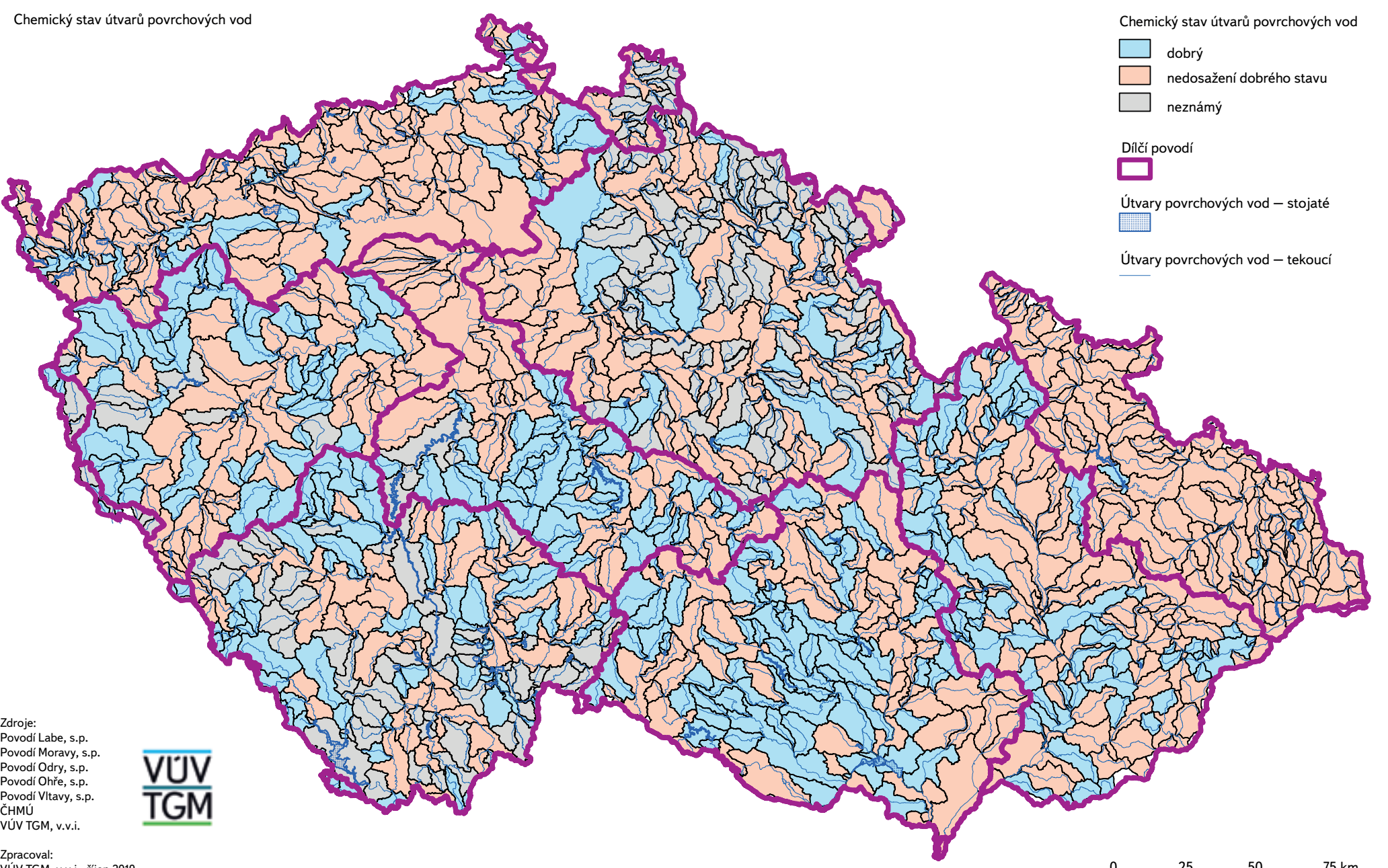

Zpracoval:

Obr. 2. Chemický stav útvarů povrchových vod za období 2016-2018 v České republice

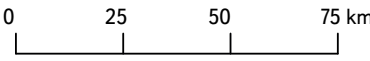

Obr. 2. Chemický stav utvaru povrchových vod za obdobi 2016-2018 v Ceské republice
Fig. 2. Chemical status of surface water bodies for the period 2016-2018 in the Czech Republic 
Tabulka 3. Chemický stav útvarů povrchových vod kategorie "reka" a "jezero"

\begin{tabular}{lll} 
Chemický stav & $\begin{array}{l}\text { Počet útvarů } \\
\text { povrchových } \\
\text { vod }\end{array}$ & $\begin{array}{l}\text { Procento } \\
\text { útvarů } \\
\text { povrchových } \\
\text { vod (\%) }\end{array}$ \\
\hline Kategorie „,̌ka“ & $\mathbf{1 0 4 5}$ & $\mathbf{1 0 0}$ \\
\hline dobrý stav & 337 & 32,2 \\
\hline nedosažení dobrého stavu & 534 & 51,1 \\
\hline stav neznámý & 174 & 16,7 \\
\hline Kategorie „jezero“ & $\mathbf{7 3}$ & $\mathbf{1 0 0}$ \\
\hline dobrý stav & 26 & 35,6 \\
\hline nedosažení dobrého stavu & 15 & 20,5 \\
\hline stav neznámý & 32 & 43,8
\end{tabular}

C. Pro 2. plánovací období nebyly ještě hodnoceny tzv. nové prioritní látky, jejichž NEK nabyly účinnosti 22. prosince 2018. Některé z těchto látek zapř́činily nedosažení dobrého chemického stavu (cybutryn, cypermethrin, dichlorvos, heptachlor + heptachlorepoxid, PFOS a terbutryn) (tabulka 4).

K významnému zlepšení došlo $v$ prípadě hodnocení rozpuštěného niklu a rozpuštěného olova, kdy byla poprvé hodnocena biodostupná koncentrace těchto kovů, která je vždy nižší než koncentrace rozpuštěné formy. Nejproblematičtějším parametrem z hlediska prekračování NEK jsou dlouhodobě rtut a PBDE ( $v$ matrici biota) a polycyklické aromatické uhlovodíky $\checkmark$ matrici voda (fluoranthen, benzo(a)pyren). Posledně jmenovaný ukazatel je problematický také z hlediska obtížného dosažení dostatečně nízké meze stanovitelnosti laboratorními technikami ve vztahu k hodnotě NEK vyjádřené jako roční průměr. Z nových prioritních látek nejsou dosahovány limity pro průměrnou roční koncentraci $v$ žádném z klasifikovaných útvarů povrchových vod u cypermetrinu, PFOS a dichlorvosu, i zde jsou limitní hodnoty (NEK) velice nízké. Nicméně nové prioritní látky jsou zatím monitorovány a klasifikovány $\checkmark$ malém počtu útvarů.

\section{Ekologický stav/potenciál}

Hodnocení ekologického stavu/potenciálu je dáno agregací dílčích hodnocení biologických složek fytoplankton, fytobentos, makrofyta, makrozoobentosu a ryby v kategorii „řeka", v prípadě kategorie "jezero" pouze fytoplankton, makrofyta a ryby, a dalších složek, mezi něž patří všeobecné fyzikálně-chemické ukazatele, specifické znečištující látky a hydromorfologie. Výsledné hodnocení ekologického stavu/potenciálu je dáno nejméně přiznivým hodnocením dané složky s výjimkou hydromorfologie.

$\checkmark$ dobrém stavu nebo $v$ dobrém a lepším potenciálu bylo za období hodnocení 2016-2018 hodnoceno pouze 5,4 \% útvarů povrchových vod kategorie "řeka" a 13,7 \% útvarů kategorie "jezero" (tabulka 5).
Table 3. Chemical status of surface water bodies in categories "river" and "lake"

\begin{tabular}{lll} 
Chemical status & $\begin{array}{l}\text { Number of } \\
\text { surface water } \\
\text { bodies }\end{array}$ & $\begin{array}{l}\text { Percentage of } \\
\text { surface water } \\
\text { bodies (\%) }\end{array}$ \\
\hline “River" category & $\mathbf{1 , 0 4 5}$ & $\mathbf{1 0 0}$ \\
\hline good status & 337 & 32.2 \\
\hline $\begin{array}{l}\text { failing to achieve good } \\
\text { status }\end{array}$ & 534 & 51.1 \\
\hline $\begin{array}{ll}\text { unknown status } \\
\text { “Lake” category }\end{array}$ & $\mathbf{7 3 4}$ & 16.7 \\
\hline good status & 26 & $\mathbf{1 0 0}$ \\
\hline $\begin{array}{l}\text { failing to achieve good } \\
\text { status }\end{array}$ & 15 & 35.6 \\
\hline $\begin{array}{l}\text { unknown status } \\
\text { (15) }\end{array}$ & 32 & 20.5 \\
\hline
\end{tabular}

B. In the third planning cycle, the monitoring of priority substances increased significantly, which led to an increased number of non-compliant bodies that were previously identified as being in good status.

C. For the second planning cycle, the so-called new priority substances have not yet been evaluated, the EQS of which entered into force on $22^{\text {nd }}$ December 2018. Some of these substances have caused the failure to achieve good chemical status (cybutryn, cypermethrin, dichlorvos, heptachlor + heptachlorepoxide, PFOS, and terbutryn) (Table 4).

There was a significant improvement in the case of the evaluation of dissolved nickel and dissolved lead, when the bioavailable concentration of these metals (which is always lower than the concentration of the dissolved form) was evaluated for the first time. In the long term, the most problematic parameters in terms of exceeding the EQS are mercury and PBDE (in the biota matrix) and polycyclic aromatic hydrocarbons in the water matrix (fluoranthene, benzo(a)pyrene). The latter pollutant is also problematic in terms of the difficulty of achieving a sufficiently low limit of quantification by laboratory techniques in relation to the EQS value expressed as an annual average. Among the new priority substances, the limits for the average annual concentration in any of the classified surface water bodies for cypermethrin, PFOS, and dichlorvos are not reached; even here, the limit values (EQS) are very low. However, new priority substances are currently monitored and classified in a small number of bodies.

\section{Ecological status/potential}

The ecological status/potential assessment is given by the aggregation of sub-assessments of the Biological quality elements phytoplankton, phytobenthos, macrophytes, macrozoobenthos, and fish in the "river" category; in the case of the "lake" category only phytoplankton, macrophytes, and fish, and other quality elements including general physico-chemical parameters, specific pollutants, and hydromorphology. The final assessment of the ecological status/potential is given by the least favourable assessment of the given quality element, with the exception of hydromorphology.

Only $5.4 \%$ of surface water bodies in the "river" category and $13.7 \%$ of bodies in the "lake" category were assessed in good status or in good and better potential during the 2016-2018 evaluation period (Table 5). 
Tabulka 4. Vybrané látky chemického stavu, kvưli kterým nebyl často dosažen dobrý chemický stav v období2016-2018

\begin{tabular}{|c|c|c|c|c|}
\hline Ukazatel & $\begin{array}{l}\text { Útvary povrchových } \\
\text { vod v nevyhovujícím } \\
\text { stavu }^{1}(\%)\end{array}$ & $\begin{array}{l}\text { Útvary povrchových } \\
\text { vod v nevyhovujícím } \\
\text { stavu (počet) }\end{array}$ & $\begin{array}{l}\text { Klasifikované } \\
\text { útvary povrchových } \\
\text { vod (počet) }\end{array}$ & $\begin{array}{l}\text { Neklasifikované } \\
\text { útvary povrchových } \\
\operatorname{vod}^{2} \text { (počet) }\end{array}$ \\
\hline fluoranten & 54,7 & 351 & 642 & 476 \\
\hline benzo(a)pyren & 99,3 & 274 & 276 & 842 \\
\hline benzo(b)fluoranten & 25,9 & 167 & 644 & 474 \\
\hline benzo(k)fluoranten & 10,6 & 68 & 643 & 475 \\
\hline benzo(g,h,i)perylen & 34,4 & 223 & 649 & 469 \\
\hline rtut' & 15,1 & 88 & 584 & 534 \\
\hline kadmium rozpuštěné & 3,9 & 29 & 741 & 377 \\
\hline cybutryn & 28,6 & 46 & 161 & 957 \\
\hline heptachlor* & 10,0 & 50 & 502 & 616 \\
\hline dichlorvos & 100 & 44 & 44 & 1074 \\
\hline PFOS** & 100 & 28 & 28 & 1090 \\
\hline cypermetrin & 100 & 15 & 15 & 1103 \\
\hline kation tributylcínu & 100 & 1 & 1 & 1117 \\
\hline $\mathrm{PBDE}^{* * *}$ & 5,6 & 24 & 429 & 689 \\
\hline DEHP**** & 2,4 & 8 & 341 & 777 \\
\hline hexachlorcyklohexan & 1,2 & 6 & 512 & 606 \\
\hline
\end{tabular}

'Procento je počitáno z klasifikovaných útvarü. 2V počtu jsou zahrnuty útvary, kde nebyl ukazatel monitorován a nebo nemohl být klasifikován.

*včetně heptachlorepoxidu, ${ }^{* *}$ perfluoroktansulfonová kyselina a její deriváty, ${ }^{* * * b r o m o v a n e ́ ~ d i f e n y l e ́ t e r y, ~}{ }^{* * *}$ bis(2-ethylhexyl)ftalát

Table 4. Selected pollutants causing failure to achieve good chemical status in 2016-2018

\begin{tabular}{|c|c|c|c|c|}
\hline Indicator & $\begin{array}{l}\text { Surface water bodies } \\
\text { failing to achieve } \\
\text { good status }(\%)\end{array}$ & $\begin{array}{l}\text { Surface water bodies } \\
\text { failing to achieve } \\
\text { good status (number) }\end{array}$ & $\begin{array}{l}\text { Classified surface } \\
\text { water bodies } \\
\text { (number) }\end{array}$ & $\begin{array}{l}\text { Unclassified } \\
\text { surface water } \\
\text { bodies }^{2} \text { (number) }\end{array}$ \\
\hline fluoranthene & 54.7 & 351 & 642 & 476 \\
\hline benzo(a)pyrene & 99.3 & 274 & 276 & 842 \\
\hline benzo(b)fluoranthene & 25.9 & 167 & 644 & 474 \\
\hline benzo(k)fluoranthene & 10.6 & 68 & 643 & 475 \\
\hline benzo(ghi)perylene & 34.4 & 223 & 649 & 469 \\
\hline mercury & 15.1 & 88 & 584 & 534 \\
\hline dissolved cadmium & 3.9 & 29 & 741 & 377 \\
\hline cybutryne & 28.6 & 46 & 161 & 957 \\
\hline heptachlor* & 10.0 & 50 & 502 & 616 \\
\hline dichlorvos & 100 & 44 & 44 & 1,074 \\
\hline PFOS** & 100 & 28 & 28 & 1,090 \\
\hline cypermethrin & 100 & 15 & 15 & 1,103 \\
\hline triphenyltin cation & 100 & 1 & 1 & 1,117 \\
\hline $\mathrm{PBDE}^{* * *}$ & 5.6 & 24 & 429 & 689 \\
\hline DEHP**** & 2.4 & 8 & 341 & 777 \\
\hline hexachlorocyclohexane & 1.2 & 6 & 512 & 606 \\
\hline
\end{tabular}

'Percentage calculated from classified bodies. ${ }^{2}$ Number includes bodies where the parameter was not monitored or could not be classified.

*including heptachlor epoxide, ** perfluorooctanesulfonic acid (PFOS) and its derivatives, ***polybrominated diphenyl ethers (PBDE), ****bis(2-ethylhexyl) phthalate 
Tabulka 5. Ekologický stav/potenciál útvarů povrchových vod kategorie "řeka"

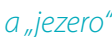

\begin{tabular}{lll}
$\begin{array}{l}\text { Ekologický } \\
\text { stav/potenciál }\end{array}$ & $\begin{array}{l}\text { Počet útvarů } \\
\text { povrchových vod }\end{array}$ & $\begin{array}{l}\text { Procento útvarů } \\
\text { povrchových } \\
\text { vod (\%) }\end{array}$ \\
\hline Kategorie „řeka“ & 1045 & 100
\end{tabular}

\begin{tabular}{lll}
\hline $\begin{array}{l}\text { velmi dobrý stav/maxi- } \\
\text { mální potenciál }\end{array}$ & 0 & 0 \\
\hline $\begin{array}{l}\text { dobrý stav/lepší } \\
\text { potenciál }\end{array}$ & 56 & 5,4 \\
\hline $\begin{array}{l}\text { střední stav/střední } \\
\text { potenciál }\end{array}$ & 635 & 60,8 \\
\hline $\begin{array}{l}\text { poškozený stav/poško- } \\
\text { zený potenciál }\end{array}$ & 272 & 26,0 \\
\hline
\end{tabular}

\begin{tabular}{lcc}
\hline $\begin{array}{l}\text { zničený stav/zničený } \\
\text { potenciál }\end{array}$ & 82 & 7,8 \\
\hline $\begin{array}{l}\text { stav/potenciál } \\
\text { neklasifikován }\end{array}$ & 0 & 0 \\
\hline
\end{tabular}

\begin{tabular}{lll}
\hline Kategorie „jezero“ & $\mathbf{7 3}$ & $\mathbf{1 0 0}$ \\
\hline dobrý a lepší potenciál & 10 & 13,7 \\
\hline střední potenciál & 29 & 39,7 \\
\hline poškozený potenciál & 10 & 13,7 \\
\hline zničený potenciál & 24 & 32,9 \\
\hline $\begin{array}{l}\text { potenciál } \\
\text { neklasifikován }\end{array}$ & 0 & 0
\end{tabular}

Hodnocení jednotlivých složek ekologického stavu/potenciálu a jednotlivých všeobecných fyzikálně-chemických ukazatelů pro kategorii "řeka" můžeme vidět na obr. 3, pro kategorii "jezero" na obr. 4. V prípadě útvarů kategorie „řeka” se na nevyhovujícím stavu podílí nejvýrazněji všeobecné fyzikálně-chemické složky $(91,9 \%)$ a teprve následně biologické složky jako celek (73,4 \%). Obdobně je tomu v prípadě kategorie "jezero“. Tento vysoký podíl nesplnění dobrého ekologického stavu/potenciálu je v prípadě rek dán použitím přísnějších typově specifických hodnot fyzikálně-chemických složek ekologického stavu [11]. Limitujícím parametrem všeobecné fyzikálně-chemické složky pro dosažení zlepšení stavu je celkový fosfor následovaný kyslíkovými poměry (řeky) a průhledností (jezera) (tabulka 6).

$\checkmark$ prípadě celkového fosforu míra prekekročení typově specifických hodnot (index nesouladu) pro dobrý stav/potenciál u řek činila v průměru 3,4 (medián činil 2,6). Nejvyšší míra překročení je typická pro drobné toky protékající lidskými sídly a nejvyšší indexy nesouladu (nad 10) byly zjištěny hlavně v dílčím povodí Dyje a Horního a středního Labe. Jen u 15 \% nevyhovujících vodních útvarů kategorie „řeka" byla míra překročení typově specifických hodnot nízká v intervalu 1,01 až 1,5. Podobně index nesouladu v nasycení vody kyslíkem (minimum) činil v průměru 2,7 (medián 1,25). U necelých 70 \% nesplňujících vodních útvarů byla v tomto ukazateli limitní hodnota mezi dobrým a středním stavem překročena jen mírně (index nesouladu do 1,5).

Table 5. Ecological status/potential of surface water bodies in categories "river" and "lake"

\section{Ecological status/potential \\ Number of surface water bodies}

\begin{tabular}{lll}
\hline “River” category & $\mathbf{1 , 0 4 5}$ & $\mathbf{1 0 0}$ \\
\hline $\begin{array}{l}\text { high status/maximum } \\
\text { potential }\end{array}$ & 0 & 0 \\
\hline $\begin{array}{l}\text { good status/better } \\
\text { potential }\end{array}$ & 56 & 5.4 \\
$\begin{array}{l}\text { moderate status/ } \\
\text { moderate potential }\end{array}$ & 635 & 60.8 \\
\hline $\begin{array}{l}\text { poor status/poor } \\
\text { potential }\end{array}$ & 272 & 26.0 \\
\hline
\end{tabular}

\begin{tabular}{lll}
\hline $\begin{array}{l}\text { bad status/bad } \\
\text { potential }\end{array}$ & 82 & 7.8 \\
\hline $\begin{array}{l}\text { status/potential } \\
\text { unclassified }\end{array}$ & 0 & 0 \\
\hline “Lake” category & $\mathbf{7 3}$ & $\mathbf{1 0 0}$ \\
\hline $\begin{array}{l}\text { good and better } \\
\text { potential }\end{array}$ & 10 & 13.7 \\
\hline moderate potential & 29 & 39.7 \\
\hline poor potential & 10 & 13.7 \\
\hline bad potential & 24 & 32.9 \\
\hline potential unclassified & 0 & 0
\end{tabular}

The assessment of individual quality elements of ecological status/potential and individual general physico-chemical parameters for the "river" category can be seen in Fig. 3, and for the "lake" category in Fig. 4. In the case of bodies in the "river" category, the General physico-chemical quality elements (91.9\%) and only subsequently the Biological quality elements as a whole (73.4\%) contribute the most to the unsatisfactory condition. The "lake" category is similar. This high rate of non-compliance with good ecological status/potential in the case of rivers is due to the use of stricker type-specific values of physico-chemical quality elements of ecological status [11]. The limiting parameter of the general physico-chemical quality element to achieve status improvement is total phosphorus, followed by oxygen conditions (rivers) and transparency (lakes) (Table 6).

In the case of total phosphorus, the rate of exceedance of type-specific values (non-compliance index) for good status/potential in rivers averaged 3.4 (median 2.6). The highest rate of exceedance is typical for small streams flowing through human settlements; the highest non-compliance indices (above 10) were found mainly in the sub-basin of the rivers Thaya and the Upper and Middle Elbe. Only in 15\% of unsatisfactory water bodies in the "river" category was the rate of exceedance of type-specific values low, in the range of 1.01 to 1.5. Similarly, the oxygen saturation non-compliance index (minimum) averaged 2.7 (median 1.25). In less than $70 \%$ of non-compliant water bodies, the limit value between good and moderate status was only slightly exceeded in this parameter (non-compliance index up to 1.5). 
Tabulka 6. Útvary povrchových vod ve středním stavu/potenciálu - všeobecné fyzikálně-chemické ukazatele

\begin{tabular}{|c|c|c|c|c|}
\hline Ukazatel & $\begin{array}{l}\text { Útvary povrchových } \\
\text { vod v horším než } \\
\text { dobrém stavu }(\%)\end{array}$ & $\begin{array}{l}\text { Počet útvarů povrchových } \\
\text { vod v horším než } \\
\text { dobrém stavu }\end{array}$ & $\begin{array}{l}\text { Počet klasifikovaných } \\
\text { útvarů povrchových } \\
\text { vod }\end{array}$ & $\begin{array}{l}\text { Počet neklasifikovaných } \\
\text { útvarů povrchových vod }{ }^{2}\end{array}$ \\
\hline \multicolumn{5}{|l|}{ Kategorie „řeka“ } \\
\hline fosfor celkový & 79,0 & 818 & 1035 & 10 \\
\hline fosfor fosforečnanový & 59,9 & 601 & 1003 & 42 \\
\hline nasycení kyslíkem & 58,2 & 596 & 1025 & 20 \\
\hline $\mathrm{BSK}_{5}$ & 40,7 & 421 & 1034 & 11 \\
\hline dusík dusičnanový & 49,7 & 518 & 1042 & 3 \\
\hline dusík amoniakální & 33,1 & 343 & 1036 & 9 \\
\hline teplota vody & 32,4 & 330 & 1019 & 26 \\
\hline reakce vody & 17,5 & 178 & 1017 & 28 \\
\hline $\mathrm{KNK}_{4,5}{ }^{*}$ & 12,1 & 16 & 132 & 913 \\
\hline \multicolumn{5}{|l|}{ Kategorie „jezero“ } \\
\hline fosfor celkový & 64,4 & 47 & 73 & 0 \\
\hline průhlednost & 80,0 & 36 & 45 & 28 \\
\hline nasycení kyslíkem & 42,6 & 23 & 54 & 19 \\
\hline reakce vody & 20,0 & 13 & 65 & 8 \\
\hline teplota vody & 11,1 & 6 & 54 & 19 \\
\hline
\end{tabular}

'Procento je počítáno z klasifikovaných útvarư. ${ }^{2} V$ počtu jsou zahrnuty útvary, kde nebyl ukazatel monitorován nebo nemohl být klasifikován.

*KNK ${ }_{4,5}$ se hodnotíjen u některých skupin útvarů.

Table 6. Surface water bodies in moderate status/potential - physico-chemical parameters

\begin{tabular}{|c|c|c|c|c|}
\hline Indicator & $\begin{array}{l}\text { Surface water } \\
\text { bodies in worse than } \\
\text { good status }(\%)\end{array}$ & $\begin{array}{l}\text { Number of water } \\
\text { bodies in worse } \\
\text { than good status }\end{array}$ & $\begin{array}{l}\text { Number of classified } \\
\text { surface water bodies }\end{array}$ & $\begin{array}{l}\text { Number of } \\
\text { unclassified surface } \\
\text { water bodies }^{2}\end{array}$ \\
\hline \multicolumn{5}{|l|}{ "River" category } \\
\hline total phosphorus & 79.0 & 818 & 1,035 & 10 \\
\hline phosphate phosphorus & 59.9 & 601 & 1,003 & 42 \\
\hline oxygen saturation & 58.2 & 596 & 1,025 & 20 \\
\hline $\mathrm{BOD}_{5}$ & 40.7 & 421 & 1,034 & 11 \\
\hline nitrate nitrogen & 49.7 & 518 & 1,042 & 3 \\
\hline ammoniacal nitrogen & 33.1 & 343 & 1,036 & 9 \\
\hline water temperature & 32.4 & 330 & 1,019 & 26 \\
\hline water reaction & 17.5 & 178 & 1,017 & 28 \\
\hline $\mathrm{ANC}_{4,5}{ }^{*}$ & 12.1 & 16 & 132 & 913 \\
\hline \multicolumn{5}{|l|}{ "Lake" category } \\
\hline total phosphorus & 64.4 & 47 & 73 & 0 \\
\hline transparency & 80.0 & 36 & 45 & 28 \\
\hline oxygen saturation & 42.6 & 23 & 54 & 19 \\
\hline water reaction & 20.0 & 13 & 65 & 8 \\
\hline water temperature & 11.1 & 6 & 54 & 19 \\
\hline
\end{tabular}

'Percentage calculated from classified bodies. ${ }^{2}$ Number includes bodies where the parameter was not monitored or could not be classified.

${ }^{*} A N C_{4.5}$ (EEA_3153-01-3 - Acid neutralizing capacity to $\mathrm{pH} 4.5$ ) is assessed only for some groups of bodies. 
Tabulka 7. Specifické znečištujici látky s významným prékročením norem environmentální kvality (NEK)

\begin{tabular}{|c|c|c|c|c|}
\hline Ukazatel & $\begin{array}{l}\text { Útvary povrchových } \\
\text { vod v horším než } \\
\text { dobrém stavu }{ }^{1}(\%)\end{array}$ & $\begin{array}{l}\text { Počet útvarů } \\
\text { povrchových vod v horším } \\
\text { než dobrém stavu }\end{array}$ & $\begin{array}{l}\text { Počet klasifikovaných } \\
\text { útvarů povrchových } \\
\text { vod }\end{array}$ & $\begin{array}{l}\text { Počet neklasifikovaných } \\
\text { útvarů povrchových vod }{ }^{2}\end{array}$ \\
\hline \multicolumn{5}{|l|}{ Kategorie „,̌̌eka“ } \\
\hline AOX & 32,1 & 157 & 488 & 557 \\
\hline metabolity alachloru & 24,2 & 143 & 591 & 454 \\
\hline EDTA & 33,7 & 93 & 276 & 769 \\
\hline bisfenol A & 17,5 & 76 & 435 & 610 \\
\hline železo & 10,2 & 66 & 649 & 396 \\
\hline metolachlor + metabolity & 9,2 & 60 & 655 & 390 \\
\hline pyren & 10,0 & 58 & 582 & 463 \\
\hline mangan & 8,7 & 51 & 583 & 462 \\
\hline fenanthren & 6,4 & 37 & 582 & 463 \\
\hline fenitrotion & 9,0 & 34 & 377 & 668 \\
\hline malathion & 7,6 & 32 & 421 & 624 \\
\hline NTA & 11,8 & 32 & 272 & 773 \\
\hline fenthion & 5,1 & 25 & 494 & 551 \\
\hline uhlovodíky C10-C40 & 4,8 & 16 & 332 & 713 \\
\hline \multicolumn{5}{|l|}{ Kategorie „jezero“ } \\
\hline AOX & 83,3 & 10 & 12 & 61 \\
\hline železo & 7,9 & 5 & 63 & 10 \\
\hline mangan & 6,0 & 3 & 50 & 23 \\
\hline bisfenol A & 10,5 & 2 & 19 & 54 \\
\hline
\end{tabular}

'Procento je počitáno z klasifikovaných útvarư. 2V počtu jsou zahrnuty útvary, kde nebyl ukazatel monitorován nebo nemohl být klasifikován.

Table 7. River basin specific pollutants with high frequency of exceedance of environmental quality standards (EQSS)

$\begin{array}{lll}\text { Indicator } & \begin{array}{l}\text { Surface water } \\ \text { bodies in worse than }\end{array} & \begin{array}{l}\text { Number of water } \\ \text { bodies in worse } \\ \text { good status }\end{array} \\ & \text { than good status }\end{array}$

Number of classified surface water bodies

\section{"River" category}

\begin{tabular}{|c|c|c|c|c|}
\hline AOX & 32.1 & 157 & 488 & 557 \\
\hline alachlor metabolites & 24.2 & 143 & 591 & 454 \\
\hline EDTA & 33.7 & 93 & 276 & 769 \\
\hline bisphenol A & 17.5 & 76 & 435 & 610 \\
\hline iron & 10.2 & 66 & 649 & 396 \\
\hline metolachlor + metabolites & 9.2 & 60 & 655 & 390 \\
\hline pyrene & 10.0 & 58 & 582 & 463 \\
\hline manganese & 8.7 & 51 & 583 & 462 \\
\hline phenanthrene & 6.4 & 37 & 582 & 463 \\
\hline fenitrothion & 9.0 & 34 & 377 & 668 \\
\hline malathion & 7.6 & 32 & 421 & 624 \\
\hline NTA & 11.8 & 32 & 272 & 773 \\
\hline fenthion & 5.1 & 25 & 494 & 551 \\
\hline hydrocarbons C10-C40 & 4.8 & 16 & 332 & 713 \\
\hline \multicolumn{5}{|l|}{ "Lake" category } \\
\hline AOX & 83.3 & 10 & 12 & 61 \\
\hline iron & 7.9 & 5 & 63 & 10 \\
\hline manganese & 6.0 & 3 & 50 & 23 \\
\hline bisphenol A & 10.5 & 2 & 19 & 54 \\
\hline
\end{tabular}

Number of unclassified surface water bodies ${ }^{2}$

'Percentage calculated from classified bodies. ${ }^{2}$ Number includes bodies where the parameter was not monitored or could not be classified. 


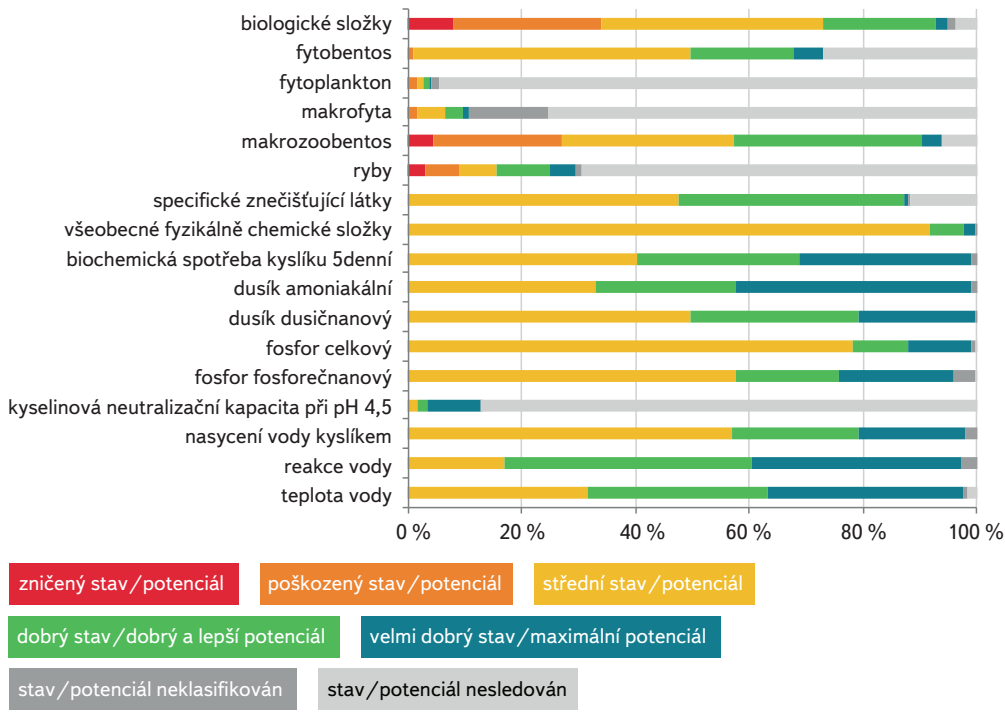

Obr. 3. Ekologický stav/potenciál útvarů povrchových vod kategorie „řkka“ podle hodnocen složek a jednotlivých všeobecných fyzikálně-chemických ukazatelů období 2016-2018 Fig. 3. Ecological status/potential of surface water bodies in the category "river" evaluated by physico-chemical parameters in 2016-2018 period

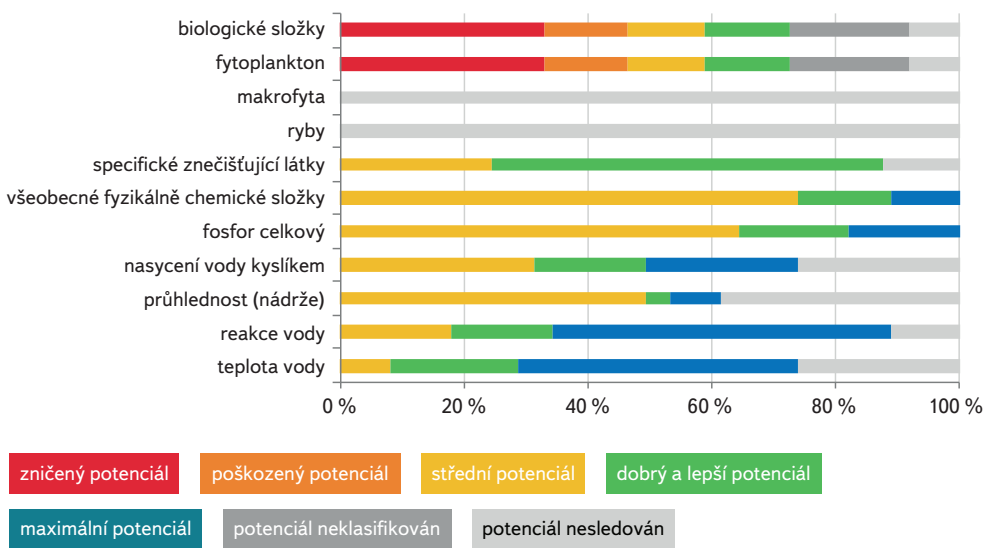

Obr. 4. Ekologický stav/potenciál útvarů povrchových vod kategorie "jezero" podle hodnocení složek a jednotlivých všeobecných fyzikálně-chemických ukazatelů období 2016-2018

Fig. 4. Ecological status/potential of the surface water bodies category "lake" evaluated by physico-chemical parameters in 2016-2018 period

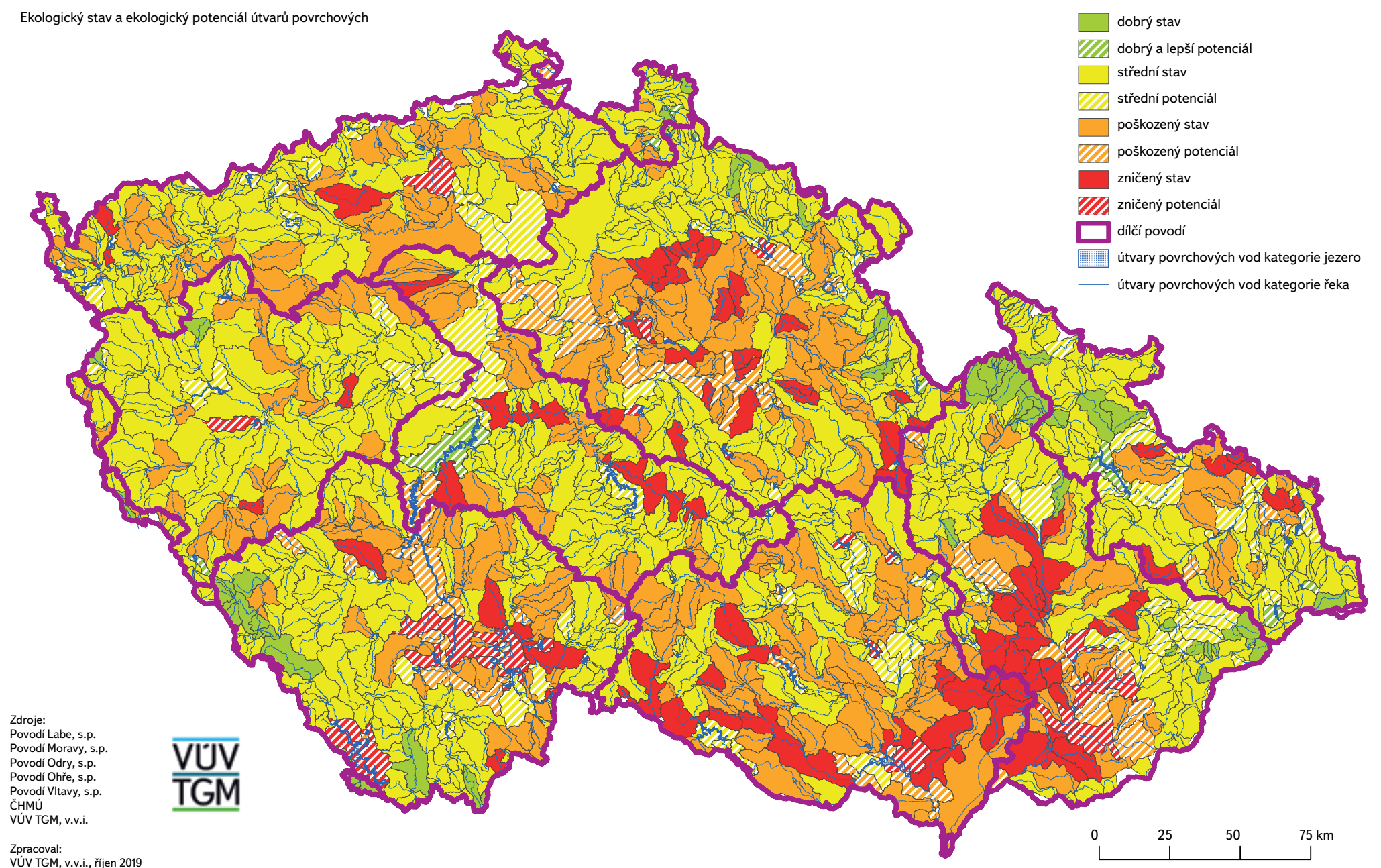


Hodnocení útvarů povrchových vod kategorie "řeka" podle biologické složky makrozoobentosu, která je nejpoužívanější biologickou složkou, vychází následovně: $32,4 \%$ ve středním stavu, 23,6 \% v poškozeném stavu a 4,8 \% ve zničeném stavu z klasifikovaných útvarů. Celkem je v nevyhovujícím stavu 599 vodních útvarů kategorie „řeka“ z 982 klasifikovaných útvarů. Počet monitorovaných útvarů povrchových vod složkou makrozoobentos byl ve srovnání s 2. plánovacím obdobím významně navýšen. Nejméně príznivý stav v této složce je patrný v útvarech povrchových vod povodí Horního a středního Labe, naopak nejlepší v povodích Dolní Vltavy a ostatních př́toků Dunaje.

Biologickou složkou fytobentos je nepř́iznivě (nevyhovující stav) hodnoceno 519 vodních útvarů kategorie „řeka“, což představuje 67,9% z 764 klasifikovaných útvarů, pouze $1 \%$ útvarů z nich je v poškozeném stavu a ve zničeném se nenachází ani jeden vodní útvar. Také u této složky došlo k významnému navýšení počtu monitorovaných vodních útvarů.

Ryby byly hodnoceny v celkem 309 vodních útvarech kategorie "řeka". Metodika hodnocení podle ryb byla v roce 2019 přepracována [5]. PIná polovina klasifikovaných vodních útvarů dobrému stavu nevyhověla (52,4\%). Na nepríznivém stavu se střední stav/potenciál podílí $22,3 \%$, poškozený stav/potenciál 19,7 \% a zničený stav/potenciál 10,4 \%. Nejméně př́iznivý stav v této složce je patrný v útvarech povrchových vod povodí Dyje, naopak nejlepší v povodí Horní Odry.

$\checkmark$ útvarech povrchových vod kategorie "jezero" byl jedinou hodnocenou biologickou složkou fytoplankton. Ze 73 vodních útvarů této kategorie byl hodnocen ekologický potenciál v 53 nádržích. Pouze 10 z nich vykazuje dobrý a lepší potenciál. Převažuje zničený potenciál ve 24 nádržích (obr. 4). Jak již bylo konstatováno v předcházejícím textu, celkový fosfor a průhlednost jsou nejvýznamnějšími faktory nesplnění požadavků pro dobrý potenciál. $V$ př́padě celkového fosforu 47 jezer nevyhovělo, míra překročení typově specifických hodnot (index nesouladu) pro dobrý potenciál činila v průměru 3,8 (medián 2,3). Nejvyšší míra překročení je typická pro rybníky. V jedné třetině vodních útvarů kategorie "jezero" byla míra překročení nízká do 1,5. Podobně míra překročení typově specifických hodnot v průhlednosti nádrže pro dobrý potenciál činila $\checkmark$ průměru 3,6 (medián 3,1). Pro 31 \% nevyhovujících nádrží byla průhlednost prekročena jen mírně (index nesouladu do 1,5).

Ze specifických znečištujujících látek k nejvíce problematickým parametrům náleží AOX, EDTA, metabolity alachloru a bisfenol A (tabulka 7). Průměrná míra překročení norem environmentální kvality (průměr) nařízení vlády č. 401/2015 Sb. [25] se u těchto parametrů pohybuje v rozmezí od 1,5 až 3,7 (1,5 u AOX, 1,65 u bisfenolu A, 2,8 pro metabolity alachloru a 3,7 pro EDTA). Toky nejvíce zatížené adsorbovatelnými organicky vázanými halogeny (AOX) se nacházejí v povodí Ohře, Dolního Labe a ostatních prítoků Labe, ovšem to je také jediné povodí, kde jsou AOX sledovány prakticky ve všech útvarech kategorie řeka.

Celkový ekologický stav/potenciál v ČR je na obr. 5.

\section{ZÁVĚR}

Z realizovaného hodnocení stavu útvarů povrchových vod zpracovaném pro 3. plánovací období při použití principu „one out - all out“ vyplývá, že v nevyhovujícím chemickém stavu je 51,1 \% útvarů povrchových vod kategorie "řeka" (z 1045 útvarů) a 20,5 \% útvarů kategorie „jezero" (ze 73 útvarů), přičemž u 16,7\% útvarů povrchových vod kategorie „reka" a u 43,8 \% útvarů kategorie "jezero" byl hodnocen jejich chemický stav jako "neznámý”. V nevyhovujícím ekologickém stavu/potenciálu je 94,6 \% útvarů povrchových vod kategorie "řeka“ (z 1045 útvarů) a 86,3 \% útvarů kategorie "jezero" (ze 73 útvarů). Hodnocení stavu bylo realizováno jako prímé hodnocení z výsledků monitorovacích programů státních podniků Povodí za období 2016-2018 s tím, že v některých opodstatněných prípadech (např. vlivem „rotování profilů monitoringu bioty) byly využity i výsledky monitorování za období 2013-2015.
The results of the assessment of surface water bodies category river according to the biological quality element of macrozoobenthos (which is the most used biological quality element) are as follows: $32.4 \%$ in the middle status, $23.6 \%$ in the poor status, and $4.8 \%$ in the bad status. A total of 599 water bodies (out of 982 classified bodies) in the "river" category are in less than good status. The number of monitored surface water bodies by the macrozoobenthos quality element was significantly increased compared to the second planning cycle. The least favourable status in this quality element is evident in the surface water bodies of the Upper and Middle Elbe river basins, while the best in the Lower Moldau river basins and tributaries of the Danube.

In total 519 water bodies in the "river" category, which represent $67.9 \%$ of 764 classified bodies, are assessed unfavourably by the biological quality element of phytobenthos (less than good status); of them, only $1 \%$ of the bodies are in a poor status and not a single water body is in the bad status. There was also a significant increase in the number of monitored water bodies in this quality element.

Fish were evaluated in a total of 309 water bodies in the "river" category. The fish assessment methodology was revised in 2019 [5]. Half of the classified water bodies did not meet good status (52.4\%). The moderate status/potential contributes $22.3 \%$ to the unfavourable status, the poor status/potential $19.7 \%$ and the bad status/potential $10.4 \%$. The least favourable status in this quality element is evident in the surface water bodies of the Thaya river basin, while the best is in the Upper Oder river basin.

In surface water bodies in the "lake" category, the only biological quality element assessed was phytoplankton. Of the 73 water bodies in this category, the ecological potential in 53 reservoirs was assessed. Only 10 of them showed good and better potential. The bad potential prevails in 24 reservoirs (Fig. 4). As stated above, total phosphorus and transparency are the most important factors in not meeting the requirements for good potential. In the case of total phosphorus, 47 lakes failed; the rate of exceedance of type-specific values (non-compliance index) for good potential averaged 3.8 (median 2.3). The highest rate of exceedance is typical for ponds. In one third of the water bodies in the "lake" category, the exceedance rate was as low as 1.5. Similarly, the rate of exceedance of type-specific values in reservoir transparency for good potential averaged 3.6 (median 3.1). For 31\% of non-compliant reservoirs, transparency was exceeded only slightly (non-compliance index up to 1.5).

Of the specific pollutants, the most problematic parameters are Adsorbable Organic Halides (AOX), ethylenediaminetetraacetic acid (EDTA), alachlor metabolites, and bisphenol A (Table 7). The average rate of exceeding EQSs (average) of Government Regulation No. 401/2015 Coll. [25] with these parameters range from 1.5 to 3.7 (1.5 for AOX, 1.65 for bisphenol A, 2.8 for alachlor metabolites, and 3.7 for EDTA). The streams most burdened by AOX are located in the Eger, Lower Elbe, and other tributaries of the Elbe river district; however, it is also the only catchment where AOX are monitored in practically all water bodies in the "river" category.

The overall ecological status/potential in the Czech Republic is shown in Fig. 5.

\section{CONCLUSION}

The implemented assessment of the surface water status prepared for the third planning cycle using the principle of "one out - all out" shows that $51.1 \%$ of surface water bodies in the "river" category (out of 1,045 bodies) and $20.5 \%$ of bodies in the "lake" category (out of 73 bodies) are failing to achieve good chemical status; in $16.7 \%$ of the surface water bodies in the "river" category and in $43.8 \%$ in the "lake" category bodies, their chemical status was assessed as "unknown". 94.6\% of surface water bodies in the "river" category (out of 1,045 bodies) and $86.3 \%$ of bodies in the "lake" category (out of 73 bodies) are in less than good ecological status/potential. The assessment was carried out as a direct 
Na nedosažení dobrého chemického stavu měly vliv predevším polycyklické aromatické uhlovodíky, konkrétně fluoranthen a benzo(a)pyren, Ize však zaznamenat rozdíly mezi jednotlivými dílčími povodími. Některé nové prioritní látky (cypermetrin, dichlorvos a PFOS) sice vycházely nevyhovující v každém sledovaném profilu, rozsah jejich sledování a klasifikace jsou však dosud velmi nízké (maximálně $4 \%$ profilů). Obdobná situace je u výsledků prioritních látek $\checkmark$ biotě pro rtut’ a bromované difenylethery (sledovány maximálně ve $3 \%$ profilů). Limitujícím parametrem pro dosažení zlepšení ekologického stavu/potenciálu je stále celkový fosfor a kyslíkové poměry pro kategorii „řeka“ a celkový fosfor a průhlednost pro kategorii "jezero“. V biologických složkách se na nepř́iznivém hodnocení útvarů povrchových vod kategorie „řeka“ podílely nejčastěji fytobentos a makrozoobentos, v kategorii „jezero" fytoplankton.

Srovnání výsledků hodnocení pro 2. a 3. plánovací období je problematické a u značné části hodnocených složek neporovnatelné z důvodu aktualizace postupů hodnocení stavu, změně identifikace silně ovlivněných útvarů pro vodní útvary kategorie řeka a významnému rozšî̌ení sledovaných ukazatelů. Možné srovnání hodnocení pro zjištění prípadného zlepšení nebo zhoršení lze tak realizovat pouze pro jednotlivé ukazatele a složky, u kterých nedošlo ke změně limitů nebo postupu hodnocení a to jen pro profily, které byly klasifikovány pro daný ukazatel v obou plánovacích obdobích. Hydromorfologie jako podpůrná složka hodnocení ekologického stavu nevstupovala do principu hodnocení "one-out - all-out". Nově byly použity původní odvozené limity mezi dobrým a středním stavem pro všeobecné fyzikálně-chemické ukazatele $\checkmark$ hodnocení ekologického stavu a biologicky dostupná forma niklu a olova $\checkmark$ hodnocení chemického stavu. Zcela přepracována byla metodika hodnocení ekologického stavu podle ryb tak, aby lépe charakterizovala stav $v$ toku a umožnila navrhovat vhodná opatření ke zlepšení. Významnou změnou byla také klasifikace chemického stavu jako neznámý v některých prípadech, kdy $\checkmark$ útvaru nebyla hodnocena žádná prioritní látka.

Podrobnější výsledky ve formě map, grafů a tabulek jsou na stránkách HEIS Vúv TGM, v. v. i.: heis.vuv.cz/projekty/rsv.

\section{Poděkování}

Děkujeme všem státním podnikưm Povodí za poskytnutá data a souhlas se zverejněním souhrnných výsledků hodnocení stavu povrchových vod. Rovněž děkujeme za poskytnutá data a výsledky ostatním spolupracujícím pracovníkưm odborných subjektü: ČHMÚ, Hydrosoft Veleslavín, s. r. o., Biologické centrum AV ČR, v. v. i.

\section{Literatura}

[1] TUŠIL, P., RICHTER, P., VYSKOČ, P., DURČÁK, M. a FILIPPI, R. Hodnocení stavu útvarů povrchových vod v České republice za období 2013-2015. Vodohospodárské technicko-ekonomické informace, 2018 roč. 60, č. 6, s. 26-33.

[2] Směrnice Evropského parlamentu a Rady 2000/60/ES ze dne 23. řijna 2000, kterou se stanovi rámec pro činnost Společenství v oblasti vodní politiky.

[3] Zákon č. 254/2001 Sb., o vodách a o změně některých zákonů (vodní zákon), ve znění pozdějších predpisů.

[4] Vyhláška č. 98/2011 Sb., o způsobu hodnocení stavu útvarů povrchových vod, způsobu hodnocen ekologického potenciálu silně ovlivněných a umělých útvarů povrchových vod a o náležitostech programů zjištování a hodnocení stavu útvarů povrchových vod, ve znění pozdějších předpisů.

[5] JANÁČ, M., JURAJDA, P., POLÁŠEK, M. a NĚMEJCOVÁ, D. Metodika hodnocení ekologického stavu útvarů povrchových vod tekoucich (kategorie reka) pomocí biologické složky ryby. Aktualizace metodického postupu Horký a Slavík (2011). Certifikovaná metodika MŽP, 2019.

[6] KOČl, M., GRULICH, V., OPATŘILOVÁ, L. a HORKÝ, P. Metodika hodnocení ekologického stavu útvarü povrchových vod tekoucich pomocí biologické složky makrofyta. Vúv TGM, v. v. i., 2011. Certifikovaná metodika MŽP. Aktualizace platná od března 2018.

[7] MARVAN, P. OPATR̈ILOVÁ, L. HETEŠA J. MACIAK, M. a HORKÝ, P. Metodika hodnocení ekologického stavu útvarů povrchových vod tekoucích (kategorie reka) pomocí biologické složky fytobentos. Vúv TGM, v. v. i., 2011. Certifikovaná metodika MŽP. Aktualizace platná od března 2018. assessment of the results of monitoring programmes of the Water Basin stateowned enterprises (Povodí) for the period 2016-2018, with monitoring results for the period 2013-2015 also being used in some justified cases (e.g. due to "rotation" of biota monitoring profiles).

The failure to achieve good chemical status was mainly influenced by polycyclic aromatic hydrocarbons, specifically fluoranthene and benzo(a)pyrene; however, differences between individual sub-basins can be noted. Although some new priority substances (cypermethrin, dichlorvos, and PFOS) failured to achieve good chemical status in each monitored profile, the scope of their monitoring and classification are still very low (maximum 4\% of profiles). The situation is similar for the results of priority substances in biota for mercury and brominated diphenyl ethers (monitored in a maximum of $3 \%$ of profiles). The limiting parameter for achieving the improvement of the ecological status/potential is still the total phosphorus and oxygen conditions for the "river" category and total phosphorus and transparency for the "lake" category. In the Biological quality elements, phytobenthos and macrozoobenthos most often contributed to the unfavourable assessment of surface water bodies in the "river" category, and phytoplankton in the "lake" category.

Comparison of evaluation results for the second and third planning cycles is problematic and incomparable for a large part of the evaluated quality elements due to the update of status assessment procedures, change of identification of heavily modified bodies for water bodies of the "river" category, and significant expansion of monitored parameters. A possible comparison of evaluations to determine possible improvement or deterioration can thus be realized only for individual parameters and quality elements for which there was no change in the limits or the evaluation procedure, and only for river profiles that were classified for the given parameter in both planning cycles. Hydromorphology as a supporting quality element of ecological status assessment did not enter the principle of "one-out - all-out" assessment. The original derived limits between good and moderate status were used for the first time for general physico-chemical parameters in the assessment of ecological status and the bioavailable form of nickel and lead in the assessment of chemical status. The methodology for assessing the ecological status of fish has been completely redesigned in order to better characterize the status of the stream and to allow the design of appropriate improvement measures. A significant change was also the classification of the chemical status as unknown in some cases where no priority substance was evaluated in the body.

More detailed results in the form of maps, graphs, and tables are on the HEIS TGM WRI, p.r.i., site: heis.vuv.cz/projekty/rsv.

\section{Acknowledgments}

We thank all the Water Basin state-owned enterprises (Povodí) for the data provided and consent to publish the summary results of the surface water status assessment. We also give thanks for the provided data and results to other cooperating employees of professional entities: CHMI, Hydrosoft Veleslavin, s.r.o., Biological Centre of the ASCR, p.r.i. 
[8] NËMEJCOVÁ, D., ZAHRÁDKOVÁ, S., OPATŘILOVÁ, L. a SYROVÁTKA, V. Metodika hodnoceníbiologické složky bentičtí bezobratlí pro velké nebroditelné reky. VÚV TGM, v. v. i., 2013. Certifikovaná metodika MŽP. Aktualizace platná od března 2018

[9] OPATŘILOVÁ, L., KOKEŠ, J., NĚMEJCOVÁ, D., SYROVÁTKA, V., ZAHRÁDKOVÁ, S., MACIAK, M. a HORKYY, P. Metodika hodnocení ekologického stavu útvarü povrchových vod tekoucích (kategorie reka) pomocí biologické složky makrozoobentos. VúV TGM, v. v. i., 2011, Certifikovaná metodika MŽP. Aktualizace platná od března 2018

[10] OPATŘILOVÁ, L., DESORTOVÁ, B., POTUŽÁK, J., LIŠKA, M., MACIAK, M. a HORKÝ, P. Metodika hodnocení ekologického stavu útvarü povrchových vod tekoucích pomoci biologické složky fytoplankton. Vúv TGM, v. v. i., 2011. Certifikovaná metodika MŽP. Aktualizace platná od března 2018.

[11] ROSENDORF, P., TUŠIL, P., DURČÁK, M., SVOBODOVÁ, J., BERÁNKOVÁ, T. a VYSKOČ, P. Metodika hodnocení všeobecných fyzikálně-chemických složek ekologického stavu útvarů povrchových vod tekoucich. Vúv TGM, v. v. i., 2011. Certifikovaná metodika MŽP.

[12] DURČÁK, M., TUŠIL, P., MIČANÍK, T., ROSENDORF, P., KRISTOVÁ, A. a VYSKOČ, P. Metodika hodnocení ekologického stavu/potenciálu útvarů povrchových vod-specifickéznečištujicil látky. Vúv TGM, v. v. i., 2013. Certifikovaná metodika MŽP.

[13] OPATŘILOVÁ, L., NĚMEJCOVÁ, D., ZAHRÁDKOVÁ, S., HORKÝ, P., DESORTOVÁ, B. a TUŠIL, P. Metoda pro hodnoceni ekologického potenciálu silně ovlivněných a umělých vodních útvarů - kategorie reka. VúV TGM, v. v. i., 2013. Certifikovaná metodika MŽP.

[14] BOROVEC, J., HEJZLAR, J., ZNACHOR, P., NEDOMA, J., ČTVRTLIIKOVÁ, M., BLABOLIL, P., ŘÍHA, M. KUBEČKA, J., RICARD, D. a MATĚNA, J. Metodika pro hodnoceni ekologického potenciálu silně ovlivněných a umělých vodnich útvarů - kategorie jezero. Biologické centrum AV ČR, v. v. i., 2014. Certifikovaná metodika MŽP.

[15] ROSENDORF, P. a PRCHALOVÁ, H. Metodika hodnocení všeobecných fyzikálně-chemických složek ekologického potenciálu útvarů povrchových vod kategorie reka. Vúv TGM, v. v. i., 2019.

[16] DURČÁK, M, TUŠIL, P, MIČANIKK, T, ROSENDORF, P, KRISTOVÁ, A a VYSKOČ P. Metodika hodnocení chemického stavu útvarů povrchových vod. Vúv TGM, v. v. i., 2013. Certifikovaná metodika MŽP.

[17] MIČANIK, T., DURČÁK, M. a KRISTOVÁ, A. Metodika odvození biologicky dostupných koncentrací vybraných kovư pro potreby hodnocení chemického stavu útvarů povrchových vod. Vúv TGM, v. v. i., 2019 Certifikovaná metodika MŽP.

[18] PRCHALOVÁ, H., DURČÁK, M., VYSKOČ, P., ROSENDORF, P. a MIČANÍK, T. Metodika hodnocení chemického a ekologického stavu útvarů povrchových vod kategorie reka pro třetí cyklus plánů povodív ČrR. Vúv TGM, v. v. i., 2019.

[19] Metal Bioavailability Assessment Tool (M-BAT), verze 30.0 z 20. listopadu 2013. Dostupný z: https:// www.wfduk.org/resources/rivers-lakes-metal-bioavailability-assessment-tool-m-bat)

[20] Biotic Ligand Model (Bio-met), verze 5.0 z června 2019. Dostupný po registraci z: http://bio-met.net/

[21] Rozhodnutí Komise 2018/229/EU ze dne 12. února 2018, kterým se podle směrnice Evropského parlamentu a Rady 2000/60/ES stanoví hodnoty pro klasifikace monitorovacích systémů členských států vyplývající z mezikalibračního porovnání a kterým se ruší rozhodnutí Komise 2013/480/EU.

[22] HORKÝ, P. Metodika hodnocení ekologického stavu útvarů povrchových vod tekoucích (kategorie reka) pomocíbiologickésložky ryby. Vúv TGM, v. v. i., 2011.

[23] KOŽENÝ, P., VYSKOČ, P., MAKOVCOVÁ, M., UHLÍROOVÁ, K., BALVÍN, P., PRCHALOVÁ, H. a kol. Pracovní postup určenívýznamných vlivư na morfologii a hydrologický režim. VÚV TGM, v. v. i., 2019.

[24] Guidance Document No. 35 - CIS WFD - WFD Reporting Guidance 2016, Final - Version 6.0.6, 2016.

[25] Nařízení vlády č. 401/2015 Sb., o ukazatelích a hodnotách přípustného znečištění povrchových vod a odpadních vod, náležitostech povolení k vypouštění odpadních vod do vod povrchových a do kanalizací a o citlivých oblastech.

\section{Autoři}

Ing. Tomáš Mičaník, Ph.D.

凶tomas.micanik@vuv.cz

ORCID: 0000-0002-5867-0985

\section{Ing. Petr Vyskoč}

凶 petr.vyskoc@vuv.cz

ORCID: 0000-0002-5006-5414

RNDr. Hana Prchalová

凶hana.prchalova@vuv.cz

ORCID: 0000-0003-1890-8335

\section{Mgr. Marek Polášek}

凶marek.polasek@vuv.cz

ORCID: 0000-0003-3213-7135

RNDr. Denisa Němejcová

$凶$ denisa.nemejcova@vuv.cz ORCID: 0000-0001-9255-442X

\section{Ing. Martin Durčák}

凶martin.durcak@vuv.cz

ORCID: 0000-0002-1999-3773

\section{Ing. Pavel Richter, Ph.D.}

凶pavel.richter@vuv.cz

ORCID: 0000-0001-6338-348

Výzkumný ústav vodohospodářský T. G. Masaryka, v. v. i. TGM Water Research Institute, p.r.i.

Príspěvek prošel lektorským rrízením.

DOI: 10.46555/VTEI.2020.09.002 